\title{
REV1 Gene
}

National Cancer Institute

\section{Source}

National Cancer Institute. REV1 Gene. NCI Thesaurus. Code C106283.

This gene plays a role in repair of DNA during replication. 